\title{
Exploration of preliminary phytochemical studies of roots of ficus racemosa
}

\author{
Krishna Murti ${ }^{1}$, Upendra Kumar' ${ }^{2}$, Mayank Panchal ${ }^{3}$, Megha Shah ${ }^{3}$
}

\begin{abstract}
Micromorphological characters for Ficus racemosa are not reported. It is used in Ayurveda for the treatment of diarrhea, dysentery and piles, rheumatism, skin disorders like sores, teeth disorders, to boost immune system, as a hypoglycemic. Literature reports the number of uses like anthelmentic, astringent, antidiabetic and anti-inflammatory activity of this plant. The main constituents in the plant are carbohydrates, glycosides, tannins, steroids, gums, mucilage, lupeol, ceryl behenate, lupeol acetate, $\alpha$-amyrin acetate, leucoanthocyanidin, and leucoanthocyanin. It is characterized by the presence of thick walled cork, several layered regularly arranged. Epidermis is thin walled and single layered, cortex and hypodermis is distinct, fibres and vessels are lignified, medullary rays are thick walled and lignified. Centre is occupied by the pith which is thin walled and has parenchymatous cells. Phytochemical investigation of root shows, total ash $(7.0 \% \mathrm{w} / \mathrm{w})$, acid insoluble ash $(3.0 \%$ $\mathrm{w} / \mathrm{w})$, and water soluble ash $(4.0 \% \mathrm{w} / \mathrm{w})$. Loss on drying is $1.584 \% \mathrm{w} / \mathrm{w}$. Alcohol soluble extractive value $(3.2 \% \mathrm{w} / \mathrm{w})$, water soluble extractive value $(10.4 \% \mathrm{w} / \mathrm{w})$, chloroform soluble extractive value $(1.06 \% \mathrm{w} / \mathrm{w})$ and ether soluble extractive value $(4.8 \% \mathrm{w} / \mathrm{w})$. Alcoholic and aqueous extracts obtained from the plant are $10.6 \% \mathrm{w} / \mathrm{w}$ and $9.2 \% \mathrm{w} / \mathrm{w}$. In alcoholic extract and aqueous extract, tannins and saponins are present in in major amount respectively. Other constituents include carbohydrate, glycosides, phenolic compounds, gums and mucilage were present.
\end{abstract}

KEY WORDS: Ficus racemosa, peepal, phytochemical investigation.

\section{INTRODUCTION}

Since ancient times, plants have been an exemplary source of medicine. Ayurveda and other Indian literature mention the use of plants in treatment of various human ailments. Plants have been the major source of drugs in Indian system of medicine and other ancient systems in the world. Earliest description of curative properties of medicinal plants is found in Rig-Veda. Charaka Samhita and Sushrusha Samhita give extensive description on various medicinal herbs. Information on medicinal plants in India has been systematically organized (1-4). India has an ancient heritage of traditional medicine. The Materia Medica of India provides a great deal of information on the folklore practices and traditional aspects of therapeutically important natural products. Indian traditional medicines based on various systems including Ayurveda, Siddha, Unani and Homeopathy.
The evaluation of these drugs is primarily based on phytochemical, pharmacological and allied approaches including various instrumental techniques such as chromatography, microscopy and others. With the emerging worldwide interest in adopting and studying traditional systems and exploiting their potential based on different health care systems, the evaluation of the rich heritage of traditional medicine is essential.

The plant grows all over India in many forests and hills. It is frequently found around the water streams and is also cultivated. The tree is medium, tall, growing $10-16 \mathrm{~m}$ in height. The rich green foliage provides a good shade. The bark is reddish grey and often cracked.

The plant is large deciduous distributed all over India from outer Himalayan ranges, Punjab, Bihar, Orissa, West Bengal, Rajasthan and common in South India (5). According to Ventakamaran

\section{AFFILIATIONS}

1Vidyabharti Trust College of Pharmacy, Pharmacology,

Bharuch, India

2Azamgarh College

of Pharmacy, Pharma

Chemistry, Azamgarh, India

3Vidyabharti Trust College of

Pharmacy, Pharmacognosy,

Umrakh, India

CORRESPONDENCE

Krishna Murti

E-mail:krishnamurti74@

yahoo.co.in

Received:

01.03.2011

Revision:

26.03.2011

Accepted:

26.03.2011 
(6), the taxonomy treatment of the Moraceae family constitutes large taxa of over fifty genera and nearly 1400 species, including some important groups like Artocarpus, Morus and Ficus (7). Several species belonging to the genera of Ficus were reported to contain furanocoumarins which is an important plant phototoxins (8). Ventakamaran also claimed that Moraceae family contains phytochemistry related to flavonoids, flavonoids with isoprenoid substituents and stilbenes. Antioxidants from figs can protect lipoproteins in plasma from oxidation and produce a significant increase in plasma antioxidant capacity (9). Ficus racemosa Linn (Moraceae) is an evergreen, moderate to large sized spreading, lactiferous, deciduous tree, without much prominent aerial roots found throughout greater part of India in moist localities and is often cultivated in villages for its edible fruit (10). The astringent nature of the bark has been employed as a mouth wash in spongy gum and also internally in dysentery, menorrhagia and haemoptysis (11). All parts of this plant (leaves, fruits, bark, latex, and sap of the root) are medicinally important in the traditional system of medicine in India. The leaves powdered and mixed with honey is given in bilious infections (12).

This tree of life has also got the medicinal value. The juice of its leaves extracted by holding them near the fire can be used as the ear drop. Its power bark has been used to heal the wounds for years. The bark of the tree is useful in inflammations and glandular swelling of the neck. Their root barks is useful for stomatitis, heal ulcers, and promotes granulations. Its roots are also good for gout. The roots are even chewed to prevent gum diseases. Its fruit is laxative which promotes digestion and checks vomiting. Its ripe fruits are good for the foul taste, thirst and heart diseases. The powered fruit is taken for asthma. Its seeds have proved useful in urinary troubles. The leaves are used to treat constipation (13).

Plant is propagated using cutting of stem and root suckers. Natural regeneration is very good from seeds dispersed by animals and birds. Four months old seedling are transplanted to polythene bags and then planted in field after one month. The bark is antiseptic, antipyretic and vermicidal, and the decoction of bark is used in the treatment of various skin diseases, ulcers and diabetes. It is also used as a poultice in inflammatory swellings/boils and regarded to be effective in the treatment of piles, dysentry, asthma, gonorrhea, gleet, menorrhagia, leucorrhea, hemoptysis and urinary diseases (14).

Peepal is a large, fast growing deciduous tree. It has a heart shaped leaves. It is a medium size tree and has a large crown with the wonderful wide spreading branches. It shed its leaves in the month of March and April. The fruits of the Peepal are hidden with the figs. The figs are ripening in the month of May. The figs which contain the flowers grow in pairs just below the leaves and look like the berries. Its bark is light gray and peels in patches. Its fruit is purple in colour. It is one of the longest living trees. Peepal tree has the great importance in India especially among the Buddhist who regard Peepal tree as the personification of Buddha. Lord Buddha attained enlightenment mediating under the Peepal tree. It is regarded as the sacred tree and the people use its leaves for the religious purposes (15).

Peepal tree will receive the same reward as if he worshiped me in person. The Peepal tree has its own symbolic meaning of
Enlightenment and peace. People tie threads of white, red and yellow silk around it to pray for progeny and rewarding parenthood. Hindus in India holds the great spiritual regard for the Peepal Tree, they regard it as the tree beneath which Vishnu was born (16).

So, in the traditional system of medicine, the plant is used for various health problems and diseases (17). However, no phytochemical and pharmacological investigations of the fresh roots have been conducted so far to substantiate this practice. Therefore, the aim of this paper is to present an overview of traditional, pharmacognostical, phytochemical investigations carried out on the roots of plant Ficus racemosa.

\section{MATERIALS AND METHODS}

Collection and identification: The proposed material for study was identified and submitted as Ficus racemosa roots and it was authenticated by Associate Professor Dr. M. S. Jangid, Department of Botany, College campus, Modasa, Hemchandracharya North Gujarat University, Patan (Gujarat). The roots were collected, washed with water, dried in sunlight and stored properly. The dried roots was powdered and passed through the sieve no. 60. Coarse powder was used for phytochemical work.

Morphological studies: The morphological characters like condition, type, size, shape, apex, margin, base, surface, color, odor and taste of Ficus racemosa roots were studied (18).

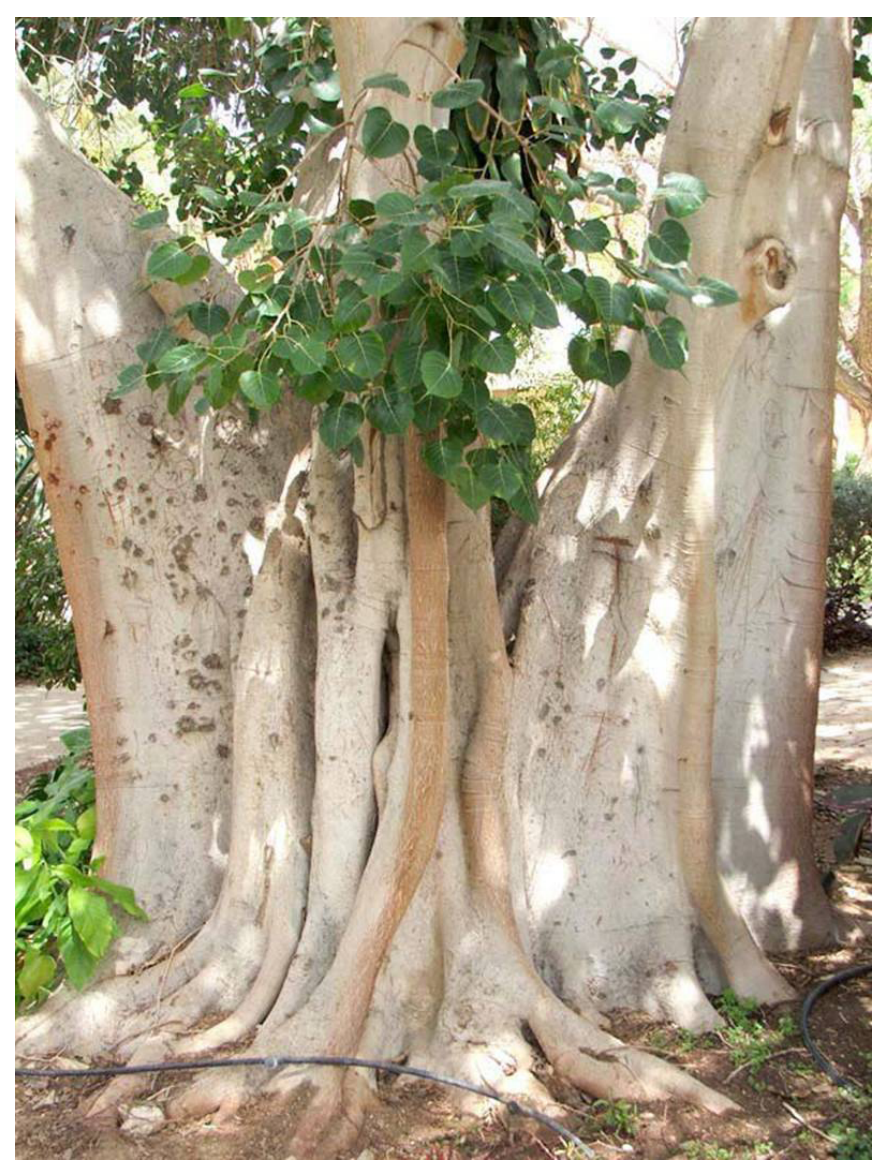

FIGURE 1. Ficus racemosa roots 


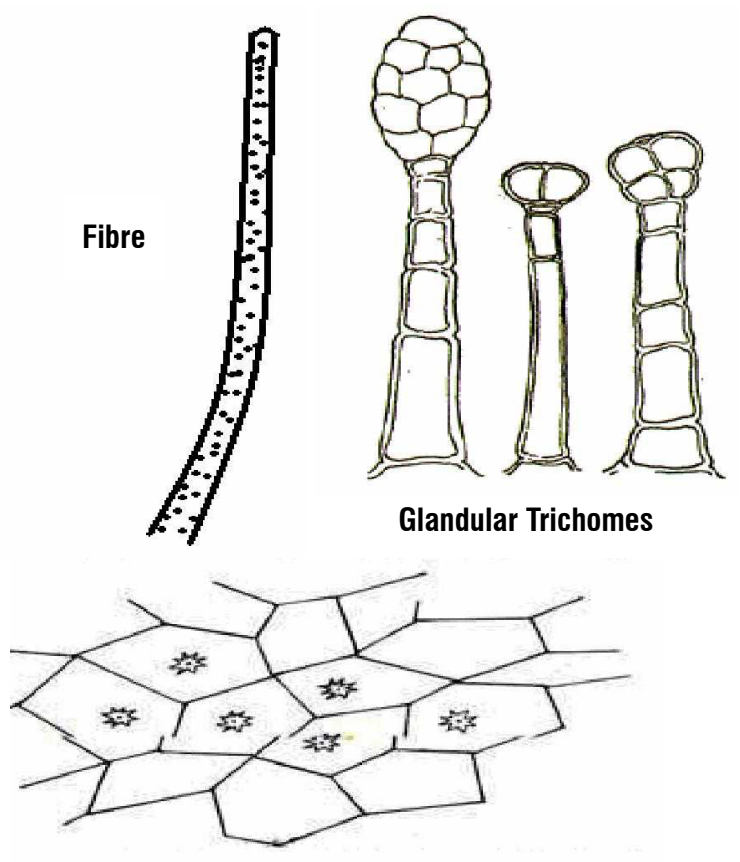

Calcium oxalate crystals

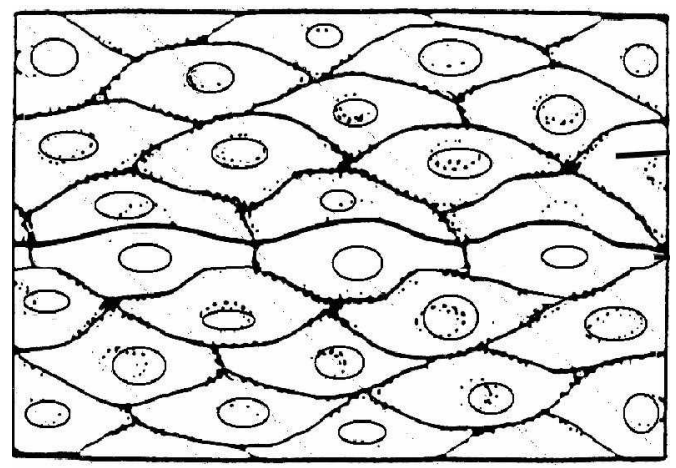

Stone cell

Microscopical characters of Ficus racemosa roots.

Microscopical studies: The required samples of Ficus racemosa roots were sectioned with the help of fresh blade. The sections were first cleared with chloral hydrate and then stained with phloroglucinol and concentrated HCL. Sections were also stained with iodine solution (I-KI) for starch.

\section{Physicochemical constants}

Ash values were used to determine the quality and purity of the crude drugs. Procedure given in Indian Pharmacopoeia was used to determine the different ash values such as total ash and acid insoluble ash. Alcohol soluble and water soluble value was also determined as per procedure given in Indian Pharmacopoeia (19).

\section{Phytochemical analysis}

The dried powder material was extracted with ethanol $(95 \%$ $\mathrm{v} / \mathrm{v}$ ) and demineralized water successively in a Soxhlet apparatus. The extracts were filtered while hot and concentrated under reduced pressure. The practical and \% yields of the ex- tracts were calculated. The concentrated ethanolic and aqueous extracts of the leaves were subjected to qualitative chemical test for the identification of various active constituents.

\section{RESULTS \\ Morphological characters}

The roots of Ficus racemosa are long, brownish in colour. It's having characteristic odour and slightly bitter in taste. Roots are irregular in shape.

\section{Microscopic characters}

The fixed, sectioned and stained plant materials as well as powder and macerated materials were studied using light microscope according to the usual microscopic techniques. The results of microscopic feature of Ficus racemosa were systematically described and illustrated. The root had thick walled cork; cortex and hypodermis was distinct; fibres, vessels and medullary rays were lignified. Centre was occupied by pith in root section. Presence of thick walled cork, several layered regularly arranged. Epidermis is thin walled and single layered, cortex and hypodermis is distinct, fibres and vessels are lignified, medullary rays are thick walled and lignified. Centre is occupied by the pith which is thin walled and has parenchymatous cells.

\section{Powder microscopy}

Powdered sample of Ficus racemosa was examined for their organoleptic properties. Microscopical evaluation of powder of roots of Ficus racemosa shows different characters. Powder sample is light brown in colour with characteristic odour and taste. Results of powder microscopy were found to be as follows.

Fibres: cylindrical, lignified with simple pits, aseptate, about 40-50 $\mu$ diameter.

Starch grains: Single and compounded with characteristic shapes

Xylem vessels: Lignified xylem vessels, tracheids with pitted wall shows pink when treated with phloroglucinol and conc. $\mathrm{HCl}$.

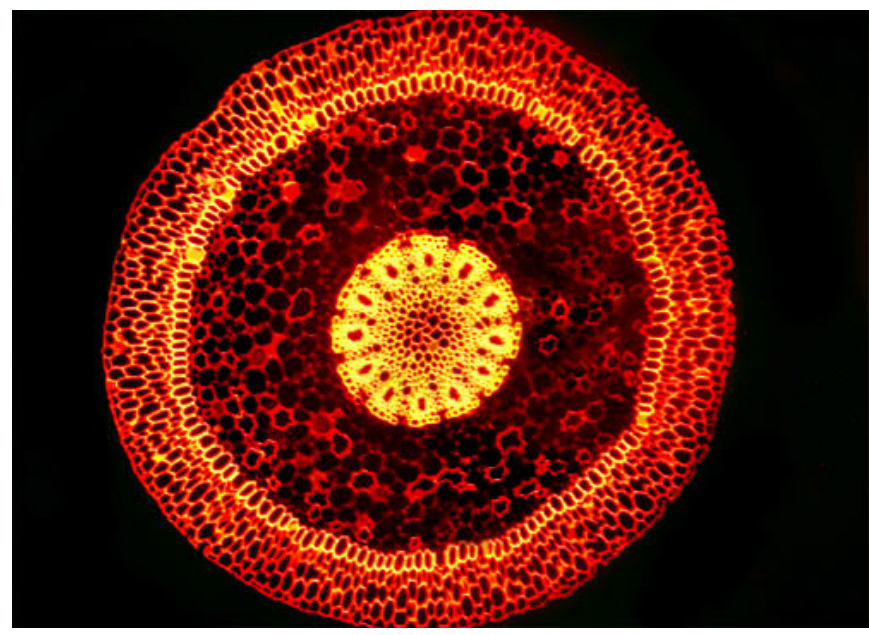

FIGURE 2. Transverse section of root. 
Cork cells: Brownish, thin walled, wavy cells containing oil globules and having several layered, regularly arranged cells.

Calcium oxalate crystals: Several calcium oxalate crystals with characteristic shapes.

\section{Physicochemical parameters}

Phytochemical investigation of root shows, total ash $11.0 \%$ $\mathrm{w} / \mathrm{w}$, acid insoluble ash $5.0 \% \mathrm{w} / \mathrm{w}$, water soluble ash $6.0 \%$ $\mathrm{w} / \mathrm{w}$, loss on drying is $1.64 \% \mathrm{w} / \mathrm{w}$. Alcohol soluble extractive value $4.8 \% \mathrm{w} / \mathrm{w}$, water soluble extractive value $11.2 \% \mathrm{w} / \mathrm{w}$, chloroform soluble extractive value $10.4 \% \mathrm{w} / \mathrm{w}$ and ether soluble extractive value $7.2 \% \mathrm{w} / \mathrm{w}$ are determined. Extracts obtained from plant are $10.6 \% \mathrm{w} / \mathrm{w}$ and $9.2 \% \mathrm{w} / \mathrm{w}$ of alcoholic and aqueous extract respectively. Other constituents includes carbohydrate, glycosides, phenolic compounds and gums and mucilage were present (20-23).

\section{DISCUSSION}

Ficus racemosa roots are frequently used as a herbal remedy for an array of human disorders including used in Ayurveda for the treatment of diarrhea, dysentery and piles, rheumatism, skin disorders like sores, teeth disorders, to boost immune system and as a hypoglycemic agent. Literature reports the number of uses like anthelmentic, astringent, antidiabetic and anti-inflammatory activity of this plant. The main constituents in the plant are carbohydrates, glycosides, tannins, steroids and gums, mucilage, lupeol, ceryl behenate, lupeol acetate, $a$-amyrin acetate, leucoantho cyanidin, and leucoanthocyanin. It is characterized by the presence of thick walled cork, several layered regularly arranged. Epidermis is thin walled and single layered, cortex and hypodermis is distinct, fibres and vessels are lignified, medullary rays are thick walled and lignified. Centre is occupied by the pith which is thin walled and has parenchymatous cells. Phytochemical investigation of leaf shows total ash $7.0 \% \mathrm{w} / \mathrm{w}$, acid insoluble ash $3.0 \% \mathrm{w} / \mathrm{w}$ and water soluble ash $4.0 \% \mathrm{w} / \mathrm{w}$. Loss on drying is $1.584 \% \mathrm{w} / \mathrm{w}$. Alcohol soluble extractive value is $3.2 \% \mathrm{w} / \mathrm{w}$, water soluble extractive value is $10.4 \% \mathrm{w} / \mathrm{w}$, chloroform soluble extractive value is $1.06 \% \mathrm{w} / \mathrm{w}$ and ether soluble extractive value is found to be $4.8 \% \mathrm{w} / \mathrm{w}$ are determined. In alcoholic extract and aqueous extract carbohydrate, glycosides, tannins, phenolic compounds and gums and mucilage were present in good quantity and saponins, alkaloids, phytosterols, fixed oils, fats, proteins, amino acids, volatile oils were absent.

\section{CONCLUSION}

In these present investigations, various pharmacognostical standization parameters such as macroscopy, microscopy, and preliminary phytochemical screening were carried out which could be helpful in authentification of Ficus racemosa. The result of the present study will also serve as reference material in the preparation of herbal monograph.

\section{REFERENCES}

1. Kirtikar KR and Basu BD Indian medicinal plants, Eds: $E$ Blatter, Caius JF, Lalit Maohan Basu, Allahabad, 2nd ed. vol. II, 1989 pp. 2389.
2. Indian medicinal plants. Eds: Ram $P$, Rastogi and Malhotra BN. Central Drug Research Institute, Luck now, Council for Scientific and Industrial Research, New Delhi vol.IV, 1989.

3. Medicinal Plants of India. Eds: Satyavati GV, Raina MK and Sharma M. Indian Council of Medical Research, New Delhi vol. IV, 1976.

4. Medicinal Plants of India. Eds Satyavati and Gupta AK. Indian Council of Medical Research, New Delhi vol. II, 1987.

5. The Wealth of India - A Dictionary of raw materials, Publications and information Directorate, CSIR, New Delhi 1956;4:35-36.

6. Ventakamaran K. Wood phenolics in the chemotaxonomy of the Moraceae. Photochemistry 1972; 11: 571-586.

7. Vishwas A, Bapat and Minal Mhatre. Ficus carica Fig, Artocarpus spp. Jackfruit and Breadfruit, and Morus spp, Mulberry. Biotechnology of fruits and nut crops, 2001, pp. 351.

8. Swain LE, Downum KR. Light-activated toxins of the Moraceae. Biochem Sys Ecol 1990, 18: 153-156.

9. Duenas M, Perez-Alonso JJ, Santos-Buelga C, EscribanoBailon T. Anthocyanin composition in fig (Ficus carica L.). J Food Compos Anal 2008, 21.

10. Anonymous. The Wealth of India. Council of Scientific and Industrial Research, New Delhi, India 1992; 35-36.

11. Chopra RN, Chopra IC, Handa KL, Kapur LD, Indigenous Drugs of India, Academic Publisher, Calcutta, 1958;2:508-674.

12. Kirtikar $K R$, Basu BD, Indian Medicinal Plants. Dehra Dun 1975;3(2): 2327-2328.

13. Cultivation and utilization of medicinal plants. Eds: Atal CK and Kapur BM. Regional Research Laboratory, CSIR, Jammu Tawi, India. 1982;514-519.

14. Nadkarni KM, Nadkarni $A K$, Chopra RN. Indian Materia Medica, Popular Prakashan, Bombay. 1976;1:548-550.

15. Medicinal plants of India, ICMR, New Delhi, Vol.I, 1956, pp. $415-416$.

16. Shivrajan VV. Ayurvedic drugs and their Plant sources, Oxford and IBH Publishing company Pvt. Ltd. New Delhi 2002, pp.333.

17. Khare CP. Encyclopedia of Indian Medicinal Plants Springer Publication. 2004;216-217.

18. Wallis TE. Text book of Pharmacognosy, CBS Publisher and Distributors. 2001, pp. 68-78.

19. Indian Pharmacopoeia. Ministry of Health and Family Welfare, Government of India, Controller of Publication, 1985, pp. 310.

20. Harbone JB. Phytochemical Method, Chapman Hall, 1985, pp. 117-119.

21. Mohammed A. Text Book of Pharmacognosy, CBS Publishers and Distributors, 1994, pp. 81-447.

22. Agrawal OP. Advanced practical organic chemistry, Goel Publishing House, 2000 pp. 43-59.

23. Divakar MC. Plant Drug Evaluation, CD Remedies Publication, 2002, pp. 49-89. 